\title{
PENGARUH PENGUMUMAN PEMBAYARAN DIVIDEN TUNAI TERHADAP PERUBAHAN RETURN SAHAM
}

\author{
Ainul Chadilla \\ Department of Management FEB UMM \\ E-mail: aniendyella@gmail.com
}

\begin{abstract}
This research aims to analyze the effect of cash devidend payment announcement on stock return. Compass 100 Index is a collection of 100 companies that have good financial performance as well as changes in the level and frequency of transactions is high prices. The result showed that there was a significant effect between cash devidend payment announcement and stock return changes. Some conditions showed an abnormal return, where in period $t-2, t 0, t 1$ and t 3 were greater than $t$ tables. It indicates that the payment announcement of cash devidend information increasing market trust and investor attractive.
\end{abstract}

Keywords: Cash Dividend Payment Announcement, Stock Return changes, Compass 100 Index

\section{PENDAHULUAN}

Perusahaan besar maupun perusahaan kecil tentu membutuhkan dana untuk kegiatan operasionalnya. Ketika perusahaan besar memerlukan dana, maka perusahaan akan menerbitkan saham atau melakukan IPO (Intial Public Offering) untuk memperoleh tambahan modal. Masing-masing perusahaan yang telah IPO kemudian melaporkan keuangannya, sehingga nilai perusahaan lebih mudah untuk diukur. Investor mempunyai beberapa pertimbangan dalam membuat keputusan, seperti harga saham, capital gain, laba perusahaan, dan pembagian dividen.

pasar modal Indonesia sempat terpuruk namun sekarang telah kembali berkembang dengan baik, sehingga menyebabkan banyaknya perubahan pada peserta pasar modal.
Kondisi ini terjadi dan menyebabkan perubahan harga saham relatif tinggi.

Harga saham akan bergerak sesuai dengan kekuatan permintaan dan penawaran yang terjadi atas harga saham di pasar sekunder. Tinggi rendahnya harga saham lebih banyak dipengaruhi oleh pertimbangan pembeli dan penjual tentang kondisi internal dan eksternal perusahaan. Investor juga menilai kemampuan emiten menghasilkan laba. Apabila laba meningkat secara teoritis harga saham juga meningkat. Investor juga menilai laporan keuangan perusahaan untuk mengestimasi keuntungan di masa mendatang.

Investasi

merupakan

kebutuhan investor bukan hanya mencari capital gain tapi juga untuk memperoleh dividen. Kebijakan dividen sangat penting untuk manajer, pemimpin dan pemegang para saham, 
hal ini penting bagi investor karena investor menilai dividen bukan hanya sebagai pendapatan tapi juga untuk menilai masa depan dari suatu perusahaan.

Menurut Agus Sartono dan Sri

Dwi Ari Ambarwati (2010), kebijakan dividen menyangkut keputusan apakah laba yang diperoleh perusahaan akan dibagikan kepada pemegang saham sebagai dividen atau akan ditahan dalam bentuk laba ditahan guna pembiayaan investasi di masa datang. Dividen berupa pembayaran yang dilakukan perusahaan kepada pemegang saham yang berasal dari pendapatan atau earning dalam bentuk kas atau saham.

Dividen dibagikan perusahaan dalam kurun waktu kuartal atau bisa sesuai kebijakan perusahaan, bahkan bisa pula dividen tidak dibagikan dengan alasan tertentu. Perusahaan juga tidak membagi dividen ketika nilai dividen yang dibagikan menurun dari tahun sebelumnya, karena ketika nilai dividen menurun berarti menunjukkan kemampuan perusahaan menghasilkan laba juga menurun. Kebijakan dividen mempunyai arti penting bagi perusahaan. Informasi keuangan tidak hanya berguna bagi perusahaan namun juga berguna bagi investor. Bagi investor yang berinvestasi ke perusahaan dalam bentuk saham, mempunyai beberapa keuntungan.

Miller dan Modigliani (dalam Sartono 2001:282) berkesimpulan bahwa reaksi investor terhadap perubahan dividen berbeda dibanding laba ditahan, namun harga saham berubah mengikuti perubahan dividen semata-mata karena adanya kandungan informasi dalam pengumuman dividen. Pada umumnya ketika perusahaan mengumumkan akan dibagi dividen permintaan akan saham naik, sehingga harga saham juga mengikuti naik. Beberapa investor lebih menyukai dividen daripada capital gain, hal ini disebakan karena dividen lebih pasti dibandingkan dengan capital gain di masa depan.

Pada penelitian sebelumnya ada yang menyebutkan bahwa pengumuman pembayaran dividen tunai tidak berpengaruh pada perubahan harga saham. Namun penelitian lain menyatakan bahwa ada pengaruh yang signifikan dari pengumuman terhadap perubahan harga saham. Kemudian penelitian ini mencoba untuk mengetahui pengaruh pengumuman pembayaran dividien tunai terhadap perubahan harga saham dengan menggunakan metode, obyek dan periode penelitian yang berbeda. Metode yang digunakan adalah event study dengan melihat pergerakan harga saham di pasar modal.

Kemudian untuk melihat reaksi maka dihitung menggunakan abnormal return pada dividen naik maupun dividen turun, hipotesis di uji dengan uji $t$ untuk mengetahui signifikansi pengaruh dari pengumuman. Selanjutnya sebagai sebuah indikator indeks diperlukan untuk mengamati pergerakan harga dari sekuritas-sekuritas. BEI mempunyai beberapa indeks. Pada tanggal 10 Agustus 2007, BEI (Bursa Efek Indonesia) bekerja sama dengan harian Kompas merilis indeks yang baru yang disebut dengan Indeks Kompas 100. Indeks ini berisi dengan 100 Saham yang berkategori mempunyai liquiditas yang baik, kapitalisasi pasar yang tinggi, 
fundamental yang kuat, serta kinerja perusahaan yang baik.

Dalam penelitian sebelumnya, obyek yang sering digunakan adalah JII (Jakarta Islamic Index) dan saham LQ 45. Berbeda dengan penelitian ini dimana obyek yang digunakan adalah saham Kompas 100. Kompas 100 merupakan saham yang memiliki liquiditas baik dari segi harga dan transaksi.

\section{TINJAUAN PUSTAKA}

Lani Siaputra dan Adwin Surja Atmadha (2006) menyimpulkan hasil pengujian terhadap perubahan return saham sebelum dan sesudah ex-dividend date ditemukan adanya perbedaan perubahan return saham yang signifikan secara statistik yang disebabkan oleh pengumuman dividen pada $70,8 \%$ sampel penelitian serta pada portofolio (gabungan) saham per tahunnya. Mayoritas harga saham akan mengalami penurunan pada saat setelah ex-dividend date. Penelitian Lani menggunakan metode Uji Beda Paired T-test dengan populasi perusahaan yang listing di BEJ tahun 2001-2004.

Investasi merupakan

komitmen atas sejumlah dana atau sumberdaya lainnya yang dilakukan pada saat ini, dengan tujuan memperoleh sejumlah keuntungan di masa datang. Seorang investor membeli sejumlah saham saat ini dengan harapan memperoleh keuntungan dari kenaikan harga saham ataupun sejumlah dividen di masa yang akan datang, sebagai imbalan atas waktu dan risiko yang terkait dengan investasi tersebut.

Harga saham adalah harga saham yang terjadi di bursa pada saat penutupan (closing price) yang terbentuk setiap akhir perdagangan saham. Harga ini merupakan harga pada pasar riil karena merupakan harga dari suatu saham pada pasar yang sedang berlangsung atau jika pasar sudah tutup. Perubahan harga saham dipengaruhi oleh kinerja keuangan perusahaan yang bersangkutan, disamping dipengaruhi oleh permintaan dan penawaran. Salah satu karakteristik utama pasar modal yang efisien adalah bahwa informasi tersedia untuk semua pelaku pasar modal.

Informasi hanya memiliki nilai untuk jangka waktu yang sangat pendek, besar kemungkinan hanya dalam satuan menit. Secara teoritis terdapat tiga bentuk: (a) Weak form efficient market atau bentuk pasar efisien yang lemah, (b) Semistorng form efficient market atau bentuk pasar efisien yang agak kuat, dan (c) Strong form efisien atau bentuk pasar efisien yang kuat (Mamduh 2004: 395-400). Beberapa kalangan berpendapat bahwa kebijakan dividen tidak mempunyai pengaruh terhadap harga saham perusahaan maupun terhadap biaya modalnya. Apabila kebijakan dividen tidak mempunyai pengaruh yang signifikan, maka hal tersebut tidak relevan.

Kesimpulan utama dari teori ketidakrelevanan dividen MM adalah bahwa kebijakan dividen tidak mempengaruhi tingkat pengembalian yang disyaratkan atas ekuitas. Kesimpulan ini telah diperdebatkan dengan hangat dikalangan akademik. Khususnya, Myron Gordon dan John Lintner yang berendapat bahwa $\mathrm{k}_{\mathrm{s}}$ akan turun apabila rasio pembagian dividen dinaikkan karena para investor kurang yakin terhadap penerimaan keuntungan modal 
(capital gain) yang akan dihasilkan dari laba yang ditahan dibandingkan dengan seandainya mereka menerima dividen.

Ada tiga alasan yang berkaitan dengan pajak untuk beranggapan bahwa investor mungkin lebih menyukai pembagian dividen yang rendah daripada yang tinggi: (1)keuntungan modal dikarenakan pajak dengan tarif maksimum 28 persen, sedangkan pendapat dividen dikarenakan pajak dengan tarif efektif mencapai 39,6 persen (2) pajak atas keuntungan tidak dibayarkan sampai saham terjual. Adanya keuntungankeuntungan pajak ini menyebabkan para investor mungkin lebih suka perusahaan menahan sebagian besar laba perusahaan. Sehingga para investor akan mau membayar lebih tinggi untuk perusahaan yang pebagian dividennya rendah daripada untuk perusahaan sejenis yang pembagian dividennya tinggi (Bringham \& Joel 2006: 70-72).

Prosedur pembayaran aktual adalah sebagai berikut: (Mamduh 2006: 362) Declaration Date adalah hari di mana dewan direksi perusahaan mengumumkan pembayaran dividen. Ex-Dividend Date adalah dua hari sebelum tanggal pencatatan, dan ditetapkan siapa saja yang mendapatkan pembayaran dividen. Date Record adalah tanggal pencatatan di mana seluruh pemegang saham harus tercatat untuk menentukan daftar penerima dividen. Date of Payment adalah tanggal di mana cek telah dikirimkan kepada pemegang saham.

Event study merupakan studi yang mempelajari reaksi pasar terhadap suatu peristiwa yang informasinya dipublikasikan sebagai suatu pengumuman (Tandelilin 2001: 126). Apabila pengumuman mengandung informasi, maka pasar diharapkan akan bereaksi pada waktu pengumuman tersebut diterima oleh pasar. Reaksi pasar ditunjukkan dengan adanya perubahan harga dari sekuritas bersangkutan. Reaksi ini dapat diukur dengan menggunakan return sebagai nilai perubahan harga atau dengan menggunakan abnormal return.

\section{METODE PENELITIAN}

Data yang digunakan dalam penelitian ini merupakan data langsung yang diperoleh dari media online atau data sekunder. Populasi yang akan diteliti adalah Indeks Kompas 100. Teknik yang digunakan dalam mengambil sampel adalah metode purposive sampling. Sampel yang digunakan adalah 40 perusahaan Indeks Kompas 100 yang membagi dividen hingga Januari-Juni 2013.

Data yang digunakan dalam penelitian ini merupakan data langsung yang diperoleh dari media online. Data diperoleh dari www.sahamOK.com yang merupakan kumpulan perusahaan yang membayarkan dividen tunai beserta tanggal dan jumlah dividen yang dibagikan. Selanjutnya dari www.duniainvestasi.com digunakan untuk melihat harga saham harian yang berisi open price dan closing price.

Variabel dalam penelitian ini adalah dividen dan harga saham. Saham adalah surat berharga sebagai bukti penyertaan atau pemilikan individu maupun institusi dalam suatu perusahaan. Harga saham terbentuk oleh beberapa faktor antara lain seperti harapan investor terhadap 
tingkat keuntungan dividen untuk masa yang akan datang, tingkat pendapatan perusahaan, kondisi perekonomian. Dividen merupakan pembagian laba oleh perusahaan kepada para pemegang saham. Pembagian dividen ini dimaksudkan untuk meningkatkan kesejahteraan pemegang saham.

Kemudian variabel dari metode analisis yaitu event studi antara lain: Indeks Kompas 100 merupakan rata-rata harga saham harian dari 100 perusahaan yang terdaftar pada Indeks Kompas 100. Harga saham harian seluruh perusahaan dijumlahkan dan kemudian dibagi 100 sesuai dengan total seluruh perusahaan yang terdafatar. Return pasar merupakan tingkat keuntungan seluruh saham yang terdaftar Indeks Kompas 100. Return saham merupakan hasil yang diperoleh dari investasi dengan cara menghitung selisih harga saham periode berjalan dengan periode sebelumnya dengan mengabaikan dividen.

Return Ekspektasi (expected return) secara sederhana adalah ratarata tertimbang dari berbagai return historis, faktor penimbangnya adalah probabilitas masing-masing return. Abnormal Return merupakan kelebihan dari return yang sesungguhnya terjadi terhadap return normal. Return taknormal (abnormal return) adalah selisih antara return sesungguhnya yang terjadi dengan return ekspektasian. Pengujian adanya abnormal return tidak dilakukan untuk tiap-tiap sekuritas, tetapi dilakukan secara agregat dengan menguji rata-rata return taknormal seluruh sekuritas secara cross-section untuk tiap-tiap hari di periode peristiwa. Pengujian statistik terhadap return taknormal mempunyai tujuan untuk melihat signifikansi return taknormal yang ada di periode peristiwa. Signifikansi yang dimaksud adalah bahwa abnormal return tersebut secara statistik signifikan tidak sama dengan nol, artinya positif untuk kabar baik dan negatif untuk kabar buruk (Jogiyanto).

Pengujian $t$ ini dilakukan dengan cara standarisasi dari nilai return taknormal. Standarisasi yang dilakukan adalah dengan membagi nilai return taknormal dengan nilai kesalahan standar estimasinya. Kesalahan standar estimasi merupakan kesalahan standar pada waktu mengestimasi nilai abnormal return.

\section{HASIL PENELITIAN DAN PEMBAHASAN}

Selama periode penelitian ada 40 perusahaan yang diteliti. Ada kriteria pemilihan obyek yakni dari 100 perusahaan yang terdaftar di saham Kompas 100 dipilih perusahaan yang mengumumkan akan membayar dividen saham hingga Juni 2013. Periode penelitian yang digunakan adalah 4 hari periode estimasi dan 7 hari periode jendela. Penelitian ini menggunakan satu hipotesis dimana diduga ada pengaruh dari pengumuman pembayaran dividen tunai terhadap perubahan harga saham. Perhitungan pertama yang dilakukan untuk menguji hipotesis adalah return market. Return market yang merupakan tingkat pengembalian dari pasar. Return ini dibutuhkan oleh investor untuk meramalkan return dari suatu pasar yang dituju. 
Dari perhitungan pada Tabel 1 dapat dilihat bahwa tingkat pengembalian tertinggi AALI pada periode t5 sebesar 0,0367. Sedangkan untuk tingkat pengembalian terendah adalah pada periode t-4 sebesar 0,0198 . Investor sebelum berinvestasi biasanya menghitung expected return yang merupakan tingkat pengembalian yang diharapkan terjadi. Expected return diperoleh dari rata-rata Ri dibagi dengan $\mathrm{n}$ atau total seluruh populasi. Berikut adalah expected return saham AALI:

$$
\begin{aligned}
\mathrm{E}(\mathrm{Rm}) & =0,026371 / 11 \\
& =0,002397 \\
& =0,24 \%
\end{aligned}
$$

bahwa ada lima hari dimana sekuritas AALI memberi abnormal return. Salah satu dari hari yang mengalami adanya abnormal return adalah pada t-2 atau sebelum adanya pengumuman, selanjutnya terjadi pada t2, t3, t4, dan t5. Pengujian adanya abnormal return tidak dilakukan untuk tiap-tiap sekuritas, tetapi dilakukan secara agregat dengan menguji rata-rata return tak normal seluruh sekuritas secara crosssection untuk tiap-tiap hari di periode peristiwa. Hasil perhitungan pada Tabel 1 menunjukkan bahwa terjadi abnormal return pada periode $\mathrm{t}-2, \mathrm{t} 1$ dan $\mathrm{t} 2$.

Tabel 1. Return Market dan Return Saham AALI

\begin{tabular}{cccccc}
\hline Periode & $\begin{array}{c}\text { Indeks } \\
\text { Kompas }\end{array}$ & Rm & $\begin{array}{c}\text { Harga } \\
\text { Saham }\end{array}$ & Ri & RTN \\
\hline T-5 & 1102,22 & 0,0105 & 17650 & $-0,0140$ & $-0,016364$ \\
T-4 & 1109,99 & 0,0070 & 17300 & $-0,0198$ & $-0,022227$ \\
T-3 & 1113,11 & 0,0028 & 17150 & $-0,0087$ & $-0,011068$ \\
T-2 & 1101,07 & $-0,0108$ & 17400 & 0,0146 & 0,012180 \\
T-1 & 1108,21 & 0,0065 & 17300 & $-0,0057$ & $-0,008145$ \\
T0 & 1108,36 & 0,0001 & 17300 & 0,0000 & $-0,002397$ \\
T1 & 1106,23 & $-0,0019$ & 17000 & $-0,0173$ & $-0,019738$ \\
T2 & 1122,75 & 0,0149 & 17200 & 0,0118 & 0,009367 \\
T3 & 1140,33 & 0,0157 & 17450 & 0,0145 & 0,012137 \\
T4 & 1139,98 & $-0,0003$ & 17700 & 0,0143 & 0,011929 \\
T5 & 1136,99 & $-0,0026$ & 18350 & 0,0367 & 0,034326 \\
\hline Sumber: Data Diolah & & & &
\end{tabular}

Dari hasil perhitungan dapat diketahui bahwa tingkat keuntungan yang diharapkan oleh investor pada saham AALI adalah sebesar 0,002397 atau $0,24 \%$. Dari perhitungan yang telah dilakukan sebelumnya kemudian dihitung abnormal return atau tingkat pengembalian tak normal. Pada Tabel 4 dapat dilihat bahwa hasil perhitungan Eri adalah sebesar 0,002397 atau $0,24 \%$, jika dilihat dari hasil perhitungan tabel tersebut maka dapat disimpulkan
Return tak normal yang terjadi pada periode $\mathrm{t}-2$ dapat dicurigai bahwa adanya kebocoran informasi yang menyebabkan melakukan pembelian untuk memperoleh capital gain dengan menjual sahamnya pada periode setelah pengumuman. Pasar menunjukkan respon yang lambat dalam menyerap informasi yang terjadi. Pasar menunjukkan bentuk setengah kuat karena pasar belum efisien secara informasi. 
Hasil dari perhitungan ternyata menunjukkan bahwa ada pengaruh yang terjadi akibat adanya peristiwa pengumuman pembayaran dividen tunai. Pengujian statistik digunakan untuk menguji signifikansi dari return taknormal yang telah terjadi. Tingkat Kesalahan Standar Estimasi AALI:

$$
\begin{aligned}
& K S E_{i}=\sqrt{\frac{\sum_{j=t 1}^{t 2}\left(R_{i j}-\bar{R}\right)^{2}}{T 1-2}} \\
& =\frac{0,003050}{(11-7)^{1 / 2}}=0,027613
\end{aligned}
$$

Hasil dari $\mathrm{KSE}_{\mathrm{t}}$ AALI ini digunakan untuk pembagi return taknormal.

$$
\begin{aligned}
\mathrm{T} \text { tabel } & =\mathrm{t}(\mathrm{df}) \\
& =0,05(11-1) \\
& =0,05(10)=2,228
\end{aligned}
$$

Tabel 2. Hasil perhitungan Rata-rata abnormal return dan t-hitung

\begin{tabular}{ccc}
\hline Periode & RRTN & t hitung \\
\hline T-5 & $-0,003958$ & $-6,449363$ \\
T-4 & $-0,006027$ & $-2,458960$ \\
T-3 & $-0,004730$ & $-0,662572$ \\
T-2 & 0,001278 & 2,496490 \\
T-1 & $-0,000968$ & 1,942511 \\
T0 & $-0,000926$ & 2,347810 \\
T1 & 0,029002 & 3,860376 \\
T2 & 0,003914 & 2,270084 \\
T3 & $-0,010040$ & $-5,693082$ \\
T4 & $-0,002484$ & 0,178870 \\
T5 & $-0,005162$ & 2,071968 \\
\hline
\end{tabular}

Sumber: Lampiran 3

Dari Tabel 2 dapat dilihat return market dari Indeks Kompas 100 pada periode penelitian. Ada 5 hari dimana return market paling rendah adalah pada periode $\mathrm{t}-2$ sebesar $-1,08 \%$. Sedangkan periode $t 2$ dan t3 menunjukkan indeks Kompas memberi tingkat pengembalian dimana return tinggi sebesar $\mathrm{t} 2$ 1,49\% dan $\mathrm{t} 3$ 1,57\%. Return saham merupakan tingkat pengembalian dari investasi pada suatu saham atau bisa disebut juga return realisasian.

Hasil perhitungan t-test pada Tabel 2 menunjukkan bahwa terdapat signifikansi rata-rata return taknormal sekitar tanggal pengumuman yaitu pada hari $\mathrm{t}-2, \mathrm{t} 0$, $\mathrm{t} 1$ dan $\mathrm{t} 3$. Hasil ini menunjukkan bahwa ada pengaruh dari pengumuman terdapat harga saham, jadi ada kandungan informasi dari pengumuman pembayaran dividen tunai. Perbandingan $t$ hitung dan $t$ tabel dapat diketahui dan disimpulkan dengan mengabaikan tanda dari hasil perhitungan.

Hasil

perhitungan menunjukkan adanya pengaruh pengumuman pembayaran dividen tunai yang signifikan terhadap perubahan return saham. Uji t-test menunjukkan tingkat signifikansi $\mathrm{t}$ hitung $>\mathrm{t}$ tabel dengan derajat kebebasan 5\%, artinya pengaruh dari pengumuman pembayaran dividen sangat besar terutama pada periodeperiode tertentu. Hal ini dapat didasarkan atas beberapa faktor yang mendukung bahwa memang adanya pengaruh pengumuman.

Pelaku dari indeks Kompas 100 merupakan investor yang lebih memilih dividen daripada capital gain. Pemilihan ini didasarkan pada keputusan investasi dimana dividen memberikan pendapatan yang tunai dan tetap bagi investor. Abnormal return terjadi pada periode $\mathrm{t}-2$ dikarenakan sudah adanya informasi akan adanya pembagian dividen tunai pada suatu perusahaan

Informasi ini menyebabkan beberapa investor yang mengetahui informasi tersebut merespon dengan 
membeli saham dan nantinya dijual pada saat setelah pengumuman untuk mendapatkan profit atau keuntungan dari selisih harga beli dan jual, atau bisa juga untuk menghindari kenaikan harga disekitar periode pengumuman.

Pasar yang terjadi merupakan pasar bentuk semi kuat, karena informasi cenderung direspon secara lambat oleh investor. Periode dengan t hitung tertinggi adalah pada $\mathrm{t} 3$ yang artinya membutuhkan beberapa waktu sebelum investor memberi respon yang positif pada suatu pengumuman dividen. Investor tergolong sebagai klien yang lebih memilih dividen dalam berinvestasi.

Pengumuman dividen mungkin bukan hanya dilihat sebagai pengumuman pembayaran atau pembagian laba pada investor, namun dilihat sebagai pengumuman atau sinyal tentang kinerja perusahaan dimasa mendatang. Jadi ketika pengumuman menunjukkan nilai dividen naik, maka investor akan berbondong-bondong untuk berinvestasi pada perusahaan tersebut. Hasil penelitian menunjukkan bahwa terdapat kandungan informasi dalam pengumuman pembayaran dividen tunai yang kemudian oleh investor dipertimbangkan sebagai dasar pengambilan keputusan dalam berinvestasi.

\section{SIMPULAN}

Hasil perhitungan
menunjukkan bahwa terdapat
abnormal return yang signifikan
disekitar tanggal pengumuman.
Terbukti bahwa terdapat kandungan
informasi dalam pengumuman yang
kemudian menyebabkan return
saham bergerak secara signifikan

dengan merespon informasi positif yang terjadi.

Investor berharap bahwa laba perusahaan untuk selalu dibagikan dalam bentuk dividen secara periodik dengan jumlah yang selalu meningkat, dimana jumlah dividen yang dibayarkan mencerminkan kondisi kemampuan keuangan perusahaan. Kondisi lain menyatakan bahwa pasar merupakan bentuk setengah kuat, dimana informasi berpengaruh secara lambat pada penentuan keputusan investasi.

\section{DAFTAR PUSTAKA}

Ambarwati, Sri Dwi Ari. 2010. Manajemen Keuangan Lanjut. Yogyakarta: Graha Ilmu

Brigham, Eugene. F \& Joel F Houston. 2006. Dasar-Dasar Manajemen Keuangan (Fundamentals of Financial Management). Jakarta: Penerbit Salemba Empat

Darmaji, Tjiptono \& Hendy $\mathrm{M}$. Fakhruddin. 2006. Pasar Modal di Indonesia: Pendekatan Tanya Jawab. Jakarta: Penerbit Salemba Empat

Halim, Abdul. 2003. Analisis Investasi. Jakarta: Penerbit Salemba Empat

Hartono, Jogiyanto. 2010. Teori Portofolio dan Analisis Investasi. Yogyakarta: BPFE

Keown J. Arthur, dkk. 2000. Dasardasar Manajemen Keuangan (Jilid 2). Jakarta: Penerbit Salemba Empat

Kodrat, Daud Sukardi \& Kurniawan Indonanjaya. 2010. Manajemen Investasi (Pendekatan Teknikal dan Fundamental Untuk Analisis Saham). Yogyakarta: Graha Ilmu 
Sartono, Agus. 2001. Manajemen Keuangan (Teori dan Aplikasi). Yogyakarta: BPFE

Siaputra, Lani \& Adwin Surja Atmadja. 2006. Pengaruh Pengumuman Dividen Terhadap Perubahan Harga Saham Sebelum dan Sesudah ExDividend Date di Bursa Efek Jakarta (BEJ). Penelitian. Fakultas Ekonomi. Universitas Kristen Petra, Surabaya.

Suharyadi \& Purwanto, S.H. 2011. Statistika untuk Ekonomi dan Keuangan Modern. Jakarta: Penerbit Salemba Empat

Sularso R. Andi. 2003. Pengaruh Pengumuman Dividen Terhadap Perubahan harga Saham (Return) Sebelum dan Sesudah Ex-Dividend Date di Bursa Efek Jakarta (BEJ). Penelitian. Fakultas Ekonomi. Univeristas Jember
Tandelilin, Eduardus. 2001. Analisis Investasi dan Manajemen Portofolio (Edisi pertama). Yogyakarta: BPFE http://bilongtuyu.blogspot.com/2013/05/h arga-saham-berdasarkan-fungsi.html. Harga Saham Berdasarkan Fungsi. Selasa, 22 Oktober 2013

http://www.sahamok.com/dividen/dividen -2013/ . Pengumuman Pembayaran Dividen. Kamis, 17 Oktober 2013

http://www.duniainvestasi.com/bei/prices/ stock . Harga Saham Harian. Minggu, 27 Oktober 2013.

http://www.britama.com/index.php/indeks -saham-bei/indeks-kompas100/ Profil Perusahaan. Selasa, 17 Desember 2013

http://m.inilah/com/read/detail/1981303/tl km-akan-bayar-dividen-tunairp3691-per-saham. TLKM akan bayar dividen tunai Rp. 3691 per saham. Jum'at, 17 Januari 2014 